\title{
Livelihood functions of inland fisheries: policy implications in developing countries
}

\author{
Laurence E. D. Smith $^{\mathrm{a}^{*},}$ S. Nguyen Khoa ${ }^{\mathrm{c}}$ and K. Lorenzen ${ }^{\mathrm{b}}$ \\ *Corresponding author. ${ }^{a}$ Applied Economics and Business Management, Department of Agricultural Sciences, Imperial \\ College London, Wye campus, Ashford, Kent TN25 5AH UK. Tel: 0044 (0)20 7594 2699. Fax: 0044 (0)20 75942838. \\ E-mail:l.smith@imperial.ac.uk \\ ${ }^{b}$ Department of Environmental Science and Technology,Imperial College London \\ ${ }^{c}$ International Water Management Institute, Colombo
}

Received 2 October 2003; accepted in revised form 27 August 2004

\begin{abstract}
An improved analytical framework and typology of fishers are provided to improve understanding of the diverse livelihood functions of inland fishing in development policy making. Inland fisheries make an important but often neglected contribution to rural livelihoods in developing countries. A holistic and widely applicable analysis of the possible livelihood functions of such fisheries is presented, focusing on fishing as one activity within diverse livelihoods. Four different livelihood strategies are identified, involving fishing as: (i) a primary livelihood of last resort, (ii) part of a diversified semi-subsistence livelihood, (iii) a specialist occupation and (iv) part of a diversified accumulation strategy. The policy implications of these strategies are found to be differentiated and poorly represented in practice by socio-economic analysis that either undfervalues fisheries or treats them solely as livelihoods of last resort and by traditional approaches to fisheries management centred on stock conservation. The need for a more diverse and flexible range of measures, tailored to local priorities and conditions and ensuring that poor people can access the benefits of inland fisheries whilst achieving conservation objectives, is identified.
\end{abstract}

Keywords: Artisanal; Diversification; Fisheries; Fisheries management; Fishers; Impact assessment; Livelihoods; Poverty

\section{Introduction - the importance of artisanal inland fisheries in developing countries}

A fishery can be defined as the exploitation of living aquatic resources held in some form of common or open access property regime (fish account for the bulk of organisms exploited, but invertebrates such as crustacea, molluses and aquatic insects may also be important). Two aspects that distinguish fisheries from aquaculture (farming of aquatic resources) are thus the level of management intervention 
(exploitation only) and the ownership of the resource (open or common property regime) (FAO, 2000). In contrast aquaculture implies a management intervention such as feeding and private ownership of the stock being farmed. In inland and coastal aquatic systems many forms of aquatic resource use blur this distinction by combining aspects of fisheries and aquaculture. Management interventions may increase yields beyond the level achievable by capture and fishing regulation alone and are referred to as "enhancements", for example, stocking of seed-fish and habitat creation or restoration. It is also often possible to establish private access rights to freshwater fisheries.

Fisheries and aquaculture also differ significantly in their relation to natural ecosystems and their accessibility to the poor. The reliance of fisheries on ecosystems as a basis of production creates a strong congruence with conservation objectives, whilst their dependence on water resources increasingly developed for agricultural, urban and industrial uses means that they are often at the receiving end of environmental degradation. However, fishing can also have a direct environmental impact through removal of target species and the effects on the ecosystem that this causes (Welcomme, 2001; Pauly et al., 2002). In contrast aquaculture technologies tend to reduce reliance on natural ecosystems and have a more indirect though sometimes significant environmental impact (Naylor et al., 1998).

Inland fisheries require relatively few resources from those exploiting them, making them often accessible and important in the livelihoods of poor people (although there may be qualifications to this as discussed below). They are also often more important in terms of the scale and value of their contribution to food security, nutrition and employment than hunting or gathering of other open access or common property resources. In comparison aquaculture requires far more resources, such as land to build a pond, seed fish and feed, making adoption difficult for the poor and landless. Indeed it has been observed that even though aquaculture can offer benefits to poor people who lack other resources and has been promoted widely to such groups, uptake has been predominantly by higher socio-economic strata (Lewis, 1997; Lorenzen et al., 2000; Ahmed \& Lorica, 2002). This may reflect cultural factors and lifestyle preferences as well as resource constraints, as professional fishers in particular have shown little desire to take up aquaculture and the activity may be better suited to farmers than fishers (Payne, 2000).

According to FAO statistics, in 1998 inland fisheries accounted for at least $15 \%$ of total global employment in capture fisheries and aquaculture ${ }^{1}$ and produced 8 million tonnes of fish, about $10 \%$ of the total output of capture fisheries (inland and marine) (FAO, 2000). ${ }^{2}$ The exploitation status of inland fisheries varies widely, with most in Asia now heavily exploited or overexploited but much lower levels of exploitation in Latin America. With much of inland fisheries produce destined for subsistence consumption or local markets, population density relative to the abundance of water resources is a major factor driving exploitation levels.

\footnotetext{
${ }^{1}$ Total employment of 36 million including part-time and occasional workers (FAO, 2000).

${ }^{2}$ These data may be under-reported by a factor of two to three. For example, the Mekong River Commission increased its unofficial estimates of fisheries production from the Mekong Basin from approximately 300,000 to 1.2 million tonnes by including family and small-scale fishers whose catches were previously not counted (FAO, 2000). It is often difficult to assess inland fisheries as reporting may not break down the catch by species and sub-sectors (particularly own-consumption) may not be included.
} 
More than $90 \%$ of the output of inland fisheries in 1998 came from developing countries and only $3.5 \%$ from industrial countries where inland fishing has substantial economic value as a recreational activity, but involves relatively low levels of harvest. Such fisheries are particularly important in Southeast $^{3}$ and South Asia. Fish account for the bulk of animal protein consumed in countries such as Laos and Bangladesh, much of this obtained locally by part-time subsistence fishing. In Laos 80-90\% of households in the southern lowlands do some fishing and this contributes as much as $30 \%$ of rural household income (Lorenzen et al., 2000). In Cambodia, about $60 \%$ of total human consumption of animal protein is obtained from the Tonle Sap fishery alone (MRC, 1997). A beneficial nutritional impact occurs in rural areas where there are few other low cost sources of protein and micronutrients and thus even in highland areas of the Mekong Basin, for example, fish is of crucial importance in the diet (Jensen, 2001).

In Africa, fisheries can similarly be a significant component of regional economies. For example, inland fisheries in Malawi provide about $70-75 \%$ of the total animal protein consumption of both urban and rural low-income families (FAO, 1996, cited in Revenga et al., 2000). In northeast Nigeria fisheries provide employment, income, trading opportunities and valuable protein for human consumption. From $42-70 \%$ of rural households were found to earn some income from fishing and on average it contributed 24-28\% of their income (Neiland \& Sarch, 1994). ${ }^{4}$ Similarly in the Brazilian Amazon, floodplain (Varzea) households obtain about 30\% of their income from fishing (Almeida et al., 2002).

These figures illustrate that fishing and farming can be closely integrated in the livelihood strategies of rural households and that much inland fishing is done by people who do not define themselves as fishers and are not seen as such by others. Indeed in general, rural people whose livelihoods involve fishing but for whom this is not their primary or defining activity account for the largest share of inland fisheries catches. This may be well over $90 \%$ of the catch, for example in Laos (Lorenzen et al., 2000) and even in the lower Amazon where there is a well developed commercial fishery, part-time subsistence fishing still accounts for at least two-thirds of fisheries production (Almeida et al., 2002).

Freshwater ecosystems are highly biodiverse, supporting some $40 \%$ of all fish species for example, despite accounting for only a small proportion $(0.01 \%$ by volume) of aquatic habitats (Arthington et al., 2003). Subject to rising human demand for water, degradation or loss of habitat and over-fishing, aquatic biota are amongst the most threatened components of biodiversity on Earth. ${ }^{5}$ Accurate data are difficult to collect but approximately $20 \%$ of freshwater species are threatened, endangered or extinct in areas studied (Revenga et al., 2000). The protection of freshwater biodiversity is increasingly recognized as a major conservation priority (Abell et al., 2002).

\footnotetext{
${ }^{3}$ The flood plains of the Lower Mekong are among the biggest and most productive inland fisheries in the world, producing some four times as much fish per square kilometre as the North Sea, itself among the most productive marine areas in the world (Jensen, 2001).

${ }^{4}$ Results from a survey of 1500 households.

${ }^{5}$ Future species extinction rates for freshwater vertebrates are estimated to be five times higher than for terrestrial species (Revenga et al., 2000).
} 
It can be concluded that inland fisheries are a diverse resource and of particular importance to the rural poor and often to the sustainable use of freshwater ecosystems. However, despite this socio-economic and ecological importance, inland fisheries are often neglected in water resource planning and policy. ${ }^{6}$ This paper contends that this neglect stems in part from preconceived perceptions of inland fishing as a marginal and low value activity, pursued only by poor households with limited alternatives, and that these perceptions have been perpetuated by an excessively narrow analysis of fishing in much of the literature. This paper develops a more comprehensive framework for analysis of the livelihood functions and outcomes that inland fisheries can provide and uses it to identify policy priorities for improved fish and water resource management in a range of scenarios.

\section{A framework for understanding the livelihood functions of fisheries}

The livelihood functions of inland fisheries can be complex, requiring an analytical framework which can integrate assessment of a wide range of issues and which is robust, flexible and transferable. The framework developed here is holistic and widely applicable, focusing on inland fishing as one activity within rural livelihoods (the dominant mode in relation to catch as noted above) rather than on the livelihoods of fishers, as has been common in the literature. It uses a multidimensional concept of poverty and livelihoods analysis to extend an existing paradigm which has been widely used to explain why the livelihood outcomes offered by artisanal fisheries often result in poverty. It also draws upon field observations in Laos and Sri Lanka. ${ }^{7}$ Other innovations include a categorisation of the livelihood functions of fisheries and a strengthening of contemporary livelihoods analysis through greater emphasis on the role of markets and the macro-economic environment. The existing paradigm is first briefly outlined and then the improved framework is explained.

\subsection{Existing explanations of livelihood outcomes in artisanal fisheries}

Béné (2003) argues that the literature on small-scale fishing leads to the conclusion that "fisheries = poverty" (p. 955) and maintains "an overwhelming impression that fishermen are members of low-status, marginalised households" (p. 955). ${ }^{8}$ This stereotype often represents important truths, but it is also too narrow to provide a sufficiently robust and transferable model of the livelihood functions of inland fisheries. Béné (2003) describes this stereotype as the "old paradigm on poverty in small-scale fisheries" (p. 950). It is represented by Figure 1 in which the horizontal arrows represent causal links, suggesting that low incomes from fishing are determined by a combination of open access to the resource and a low opportunity cost of labour.

Open access to a fishery allows more people to enter, leading to economic (and possibly biological) overexploitation of the resource, eroding profitability and impoverishing the fishing community. Béné

\footnotetext{
${ }^{6}$ For example, a review by the authors of environmental impact assessment guidelines (including those specific to water and irrigation developments) revealed minimal coverage of inland fisheries. Payne (2000) also notes that "artisanal coastal and inland fisheries have so far been relatively neglected in policy", pg. 1.

${ }^{7}$ Part of a project to develop guidelines for improved management of the impact of irrigation on fisheries (see Lorenzen et al., 2002).

${ }^{8}$ Table 1, p. 952 in Béné (2003) lists references making this correlation between fisheries and poverty.
} 
(2003) describes this as the "endogenous origin of poverty in fisheries" (p. 951) and it can also be encapsulated by the adage "they are poor because they are fishers". 9

The influence of labour opportunity cost follows from the importance of own labour in the livelihoods of poor rural households. Own labour is the main source of power in most rural production systems in developing countries, often the main asset of the poorest households and the key determinant of household output, income and food security. Thus the return to own labour may be the main influence on the resource allocation decisions of poor households. Figure 1 assumes that low returns for labour outside the fishing sector keeps fishers' incomes at low levels through labour mobility between sectors (the argument also applies to capital, but own labour usually dominates the costs of fishing by the poor). Actual returns vary with the quality of labour and other inputs, but given open access and perfect labour mobility it can be assumed that at the margin no factor rents are earned and the marginal fishing unit just covers its opportunity cost (Cunningham, 1993). People will enter the fishery if returns for effort exceed the opportunity cost of own labour and an equilibrium number of fishers should emerge as returns for effort decline. Thus in this explanation fishing incomes depend on labour opportunity cost and not on what happens within the fishery itself (except in the short run or when barriers to entry exist). This is described by Béné (2003) as the "exogenous origin of poverty" (p. 953) and commonly through the adage "a fisher because he or she is poor" (see note 9 ).

A refinement of this explanation recognises the possibility of asymmetry in the mobility of labour, that is, that it may be easier to enter a fishery than to leave, resulting in fisher incomes even below labour opportunity cost. Possible causes include: isolation of fishing communities resulting in limited education levels, infrastructure links and alternative employment; surplus labour caused by productivity gains; investment in specific assets ${ }^{10}$ which lose market value as the fishery declines (fishers tend to be owner operators of boats and equipment); lifestyle preferences; "highliner" illusions (expectations of better catches); perverse incentives created by welfare "safety nets"; and caste restrictions, cultural factors and simple lack of knowledge of alternative occupations (Copes, 1988, cited in Cunningham, 1993; Panayotou, 1982).

Figure 1 also includes the well known idea that fisheries provide an "economic safety-valve" (Jul-Larsen \& van Zwieten, 2002, p. 40) or livelihood of "last resort" for the poor, shown as a proposition that links and reinforces the two explanations described above. This re-emphasises that people "fish because they are poor" and clearly requires a fishery to be accessible to those without alternative means of support.

\subsection{A framework for better understanding fisher livelihoods}

The following sections explain why the paradigm described above is too limited to explain adequately fisher livelihoods and suggest what is needed for a more comprehensive explanation of fishing activity and outcomes, which is widely applicable and inclusive of the diversity that is the reality of inland fisheries. The analytical approach draws on two areas of the literature on rural poverty, a

\footnotetext{
${ }^{9}$ The precise origin of this is unclear. Cunningham (1993) uses this phraseology citing McKenzie (1979, p. 816, footnote 5). The gender neutral term fisher rather than fisherman is used here.

${ }^{10}$ For which the investment cannot be recovered in a use other than that originally planned (Williamson, 1985).
} 


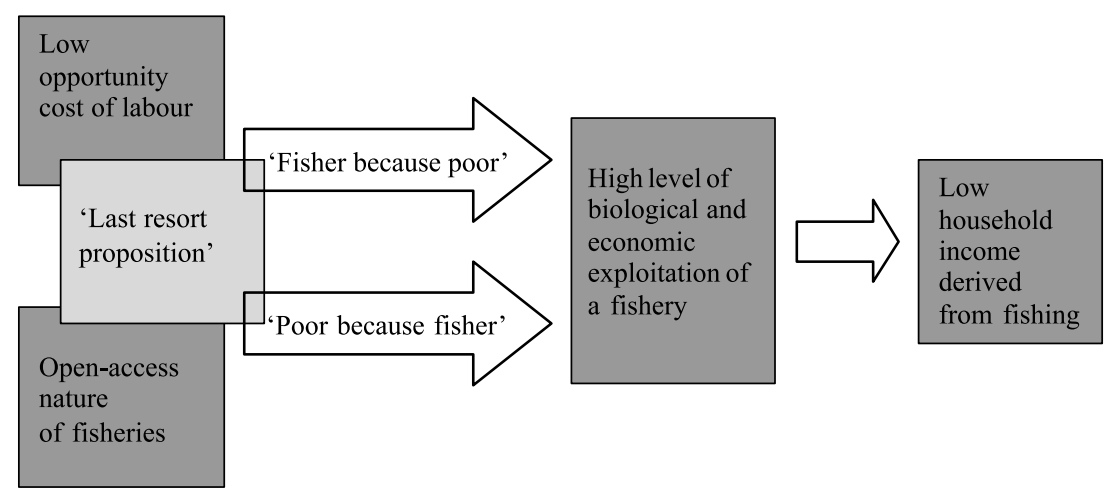

Fig. 1. Livelihood outcomes for fishers, as explained by labour opportunity cost and open resource access.

multidimensional conception of poverty and livelihoods analysis, and on an established framework for analysis of common pool resource use.

2.2.1. Poverty and livelihoods. A broad conception of the nature and causes of poverty is needed to understand the roles played by fishing in household livelihood strategies. Whilst income level is an important determinant of poverty, private consumption is not sufficient as a measure. Of main relevance to livelihoods reliant on fishing is that people may be poor for structural reasons, lacking the resources and opportunities to meet basic needs and establish a viable livelihood. Also relevant is that they may be vulnerable to "entitlement" failure, ${ }^{11}$ falling into poverty during crises such as illness, crop failure or livestock deaths, and noting that poverty is dynamic, its determinants vary both seasonally and from year to year. In addition poverty can be considered in terms of lack of access to goods and services including health, education, transport and utilities, or in terms of deprivation of economic, political, social and cultural rights. ${ }^{12}$

Livelihoods analysis encompasses these varied dimensions of poverty, defining a livelihood as comprising "the capabilities, assets (including both material and social resources) and activities required for a means of living"; and as sustainable "when it can cope with and recover from stresses and shocks and maintain or enhance its capabilities and assets both now and in the future, while not undermining the natural resource base" (DFID, 1999). Recognising that among rural communities the capacity to resist poverty and to improve livelihoods often depends on the opportunities offered by natural resource-based production systems as conditioned by the wider economic, institutional and political environment, livelihoods analysis prompts consideration of the resources or assets that are used for existence (including those owned, obtained through exchange and obtained through rights of access) and how these assets can be used in a range of activities. Variation in household access to assets is seen as a determinant of capability to cope with crises, and analysis must consider external risk factors (the "vulnerability context", DFID, 1999) and the coping mechanisms of households. This is summarised in Table 1.

\footnotetext{
${ }^{11}$ As defined by Sen (1981).

${ }^{12}$ Béné (2003) provides a more detailed review of the evolution of this multidimensional conception of poverty and its establishment as a widely accepted consensus by the late 1990s.
} 
Table 1. A framework for analysis of rural livelihoods.

\begin{tabular}{|c|c|c|c|c|c|}
\hline Assets & $\begin{array}{l}\text { For which access } \\
\text { is modified by }\end{array}$ & In a context of & $\begin{array}{l}\text { Resulting in } \\
\text { strategies }\end{array}$ & Composed of activities & $\begin{array}{l}\text { With outcomes in } \\
\text { terms of }\end{array}$ \\
\hline $\begin{array}{l}\text { Natural: } \\
\text { e.g. land, water, fish stocks, forest }\end{array}$ & $\begin{array}{l}\text { Social relations: } \\
\text {-Gender } \\
\text {-Class }\end{array}$ & $\begin{array}{l}\text { Trends: } \\
\text {-Population } \\
\text {-Migration }\end{array}$ & \multirow[t]{9}{*}{$\begin{array}{l}\text { Livelihood } \\
\text { strategies }\end{array}$} & $\begin{array}{l}\text {-Fishing } \\
\text {-Cultivation } \\
\text { (non-market) }\end{array}$ & \multirow{3}{*}{$\begin{array}{l}\text { Livelihood security: } \\
\text {-Income level } \\
\text {-Income stability } \\
\text {-Seasonality } \\
\text {-Vulnerability }\end{array}$} \\
\hline Physical: & - Age & -Technological change & & -Cultivation (market) & \\
\hline infrastructure, tools and buildings & -Ethnicity & $\begin{array}{l}\text {-Relative prices } \\
\text {-Macro policy }\end{array}$ & & $\begin{array}{l}\text {-Livestock } \\
\text {-Other hunting }\end{array}$ & \\
\hline Human: & Institutions: & -National \& world & & and gathering & \multirow{6}{*}{$\begin{array}{l}\text { Environmental } \\
\text { sustainability: } \\
\text {-Soil \& land } \\
\text { quality } \\
\text {-Water } \\
\text {-Fish stocks } \\
\text {-Forests } \\
\text {-Biodiversity }\end{array}$} \\
\hline skills, knowledge and health & $\begin{array}{l}\text {-Customary } \\
\text {-Land \& water tenure }\end{array}$ & market trends & & $\begin{array}{l}\text {-Rural manufacture } \\
\text {-Rural trade }\end{array}$ & \\
\hline $\begin{array}{l}\text { Financial: } \\
\text { income flows, savings, credit }\end{array}$ & -Markets & $\begin{array}{l}\text { Shocks: } \\
\text {-Climatic }\end{array}$ & & $\begin{array}{l}\text {-Services } \\
\text {-Farm labour }\end{array}$ & \\
\hline & Organisations: & -Market & & -Non-farm labour & \\
\hline Social: & -Associations & -Disease & & -Migration & \\
\hline $\begin{array}{l}\text { kinship networks, associations, } \\
\text { trust, access to wider institutions }\end{array}$ & $\begin{array}{l}\text {-NGOs } \\
\text {-Local admin. } \\
\text {-State agencies }\end{array}$ & -Conflict & & $\begin{array}{l}\text {-Remittances } \\
\text {-Other transfers }\end{array}$ & \\
\hline Resource endowment & \multicolumn{2}{|c|}{$\begin{array}{l}\text { Institutional and policy environment and } \\
\text { vulnerability context }\end{array}$} & \multicolumn{2}{|c|}{ Household choices and resource allocation } & Outcomes \\
\hline
\end{tabular}

Modified from Allison \& Ellis (2001). 
Using these concepts, Figure 2 provides a more comprehensive explanation of fishing activity and livelihood outcomes for fishers than Figure 1 (based on the framework for analysing the commons by Oakerson (1992). Labour opportunity cost and the degree to which a fishery is open access (Boxes E and F) remain important determinants of aggregate fishing effort and are shown explicitly in Figure 2 for continuity with the review of the fisheries literature above but, as prompted by livelihoods analysis (Table 1), are analysed both within the context of the physical, institutional and economic attributes that influence them (Boxes A to D) and as key influences on the role played by fishing in household livelihood strategies (Box G). Key elements of Figure 2 are explained further below.

2.2.2. Fishery characteristics, including fishing methods and costs. Inland fisheries in developing countries rely on diverse ecosystems and their physical attributes (Box C, Figure 2) will influence the role that fishing may play in livelihood strategies and thus levels of fishing effort and incomes. For example, empirical studies exist to support the proposition that open access leads to overexploitation and resource degradation, ${ }^{13}$ but in multi-species tropical inland fisheries, returns for effort may not decline in the continuous way suggested by traditional single-species models (Hoggarth et al., 1999; Jul-Larsen \& van Zwieten, 2002). Most tropical freshwater fisheries exploit many species of fish simultaneously, often with the same fishing gear. Species vary in their responses to exploitation, with small and short-lived ones remaining abundant and productive at much higher fishing effort than large and long-lived ones. With increasing fishing effort (number of fishers or time fished per unit area) there tends to be a shift in species composition from large to small species. The combined yield of all species increases initially with fishing effort but then levels off and remains approximately constant over a wide range of fishing pressure (Lae, 1997). The return for each fisher tends to decline with increasing overall fishing effort, but the response is non-linear and may involve phases where returns are constant or even increase with increasing pressure. These patterns suggest that tropical inland fisheries can provide benefits over a wide range of exploitation levels, even though high fishing effort will result in catches consisting predominantly of small and less valuable species. Thus the results of high exploitation levels can be more differentiated and complex than Figure 1 suggests.

Figure 2 also shows that fishery characteristics (Box C) and the institutional environment (Box D) together influence access to the resource (Box F). Open access tends to be assumed for artisanal fisheries that are community based, with the expectation that they are organisationally weak and have poor information and limited capacity to restrict access or represent their interests in policy and planning processes. Water bodies can be large, fish very mobile and supporting state regulation weak, so that even where ownership or access rights for the community are formally recognised, ability to manage and control resources may be limited. However, restricted access and effective community-based management can be common in smaller and isolated water bodies where stocks are confined, the "community" well defined and monitoring relatively easy. It is also often possible for individuals to acquire exclusive fishing rights in such water bodies from communities or government bodies.

Another common assumption underlying Figure 1 is that the entry costs to inland fishing are low, but even when considered only in terms of gear requirements (and not factor opportunity costs) this may not universally hold true. Box C (Figure 2) thus highlights the need for assessment of the cost structure of fishing practices. Open access requires that rural households can readily finance any necessary fixed and

\footnotetext{
${ }^{13}$ Table 2, p. 953 in Béné (2003) lists examples.
} 
Situational variables

(A) Micro, meso \& macro economic environment: -vulnerability: seasonality, shocks, trends -labour market: farm and non-farm employment -population pressure, availability of land and other common property resources

-effective demand and degree of access to, and integration of, local and wider markets for goods and services, including credit.

(B) Fisher characteristics:

-household asset endowments

-livelihood objectives: food security, nutrition, income,

risk management, cash source, social networks,

recreation, last resort.

(C) Fishery characteristics:

-seasonality \& resilience of combined yields

-scope for part-time fishing, passive fishing and

economies of scale

-costs of fishing: human and financial capital, gear,

skill, etc

-specific assets, isolation, preferences, social factors,

perverse incentives

-accessibility of markets and effective demand for fish.

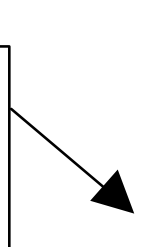

(D) Institutional environment: social, cultural and political determinants of access to a fishery, other CPRs and factors of production

-processes of discrimination: social marginalisation, class exploitation, political disempowerment (Bene, 2003)

-state and/or community capacity for fishery

management/enhancement, and of wider governance

structures.

Fig. 2. A framework for understanding determinants of livelihood outcomes in inland fisheries.

working capital and that the knowledge and skills needed can be easily obtained. Although inland fisheries are mainly characterised by low capitalisation and mechanisation (Payne, 2000), wide variation in fishing methods and corresponding financial and human capital costs can be observed (Table 2). This variation occurs not only across fisheries and communities but also the fishing practices of a single household. Sources are the physical characteristics of water bodies and fish species and the seasonality of optimal periods for fishing. For example, in Laos it is not unusual for a single household to use 20 to 30 different methods of fishing, depending on the season, species targeted and characteristics of the fisher such as gender or age (Garaway, 1999).

An absence of institutional restrictions combined with affordable costs for the purchase or selfmanufacture of fishing gear and attainable knowledge and skill requirements ${ }^{14}$ clearly can result in low barriers to entry to fishing. ${ }^{15}$ What is affordable, however, is relative to income and ability to access credit. Thus the variation in methods and costs emphasised here can mean that whilst some form of

\footnotetext{
${ }^{14}$ These are never likely to be insignificant, but can often be learned within the community at low cost though observation and by assisting others. For example, fishers in Sri Lanka explained that they learned to fish as children while helping others. Adult entrants to fishing also learned by first assisting experienced fishers.

${ }^{15}$ Descriptions of Thai fisheries by Panayotou \& Panayotou (1996) and African fisheries by Jul-Larsen \& van Zwieten (2002) are two of several examples.
} 
Table 2. Range of inland fishing methods and their cost characteristics.

\begin{tabular}{|c|c|c|}
\hline Labour intensity & Fishing methods/gears & Cost characteristics \\
\hline 'Passive fishing' (set and wait gears) & $\begin{array}{l}\text { e.g. } \\
\text { - gill nets } \\
\text { - portable traps } \\
\text { - hook \& line } \\
\text { - barrier traps }\end{array}$ & $\begin{array}{l}\text { - fixed costs range from very low to moderate } \\
\text { - low variable costs (labour) } \\
\text { - low energy requirements } \\
\text { - lower skill requirements } \\
\text {-risk of losses: theft, gear damage }\end{array}$ \\
\hline 'Active fishing' (chasing gears) & $\begin{array}{l}\text {-spears } \\
\text { - drag net } \\
\text {-cast net } \\
\text { - scoop net } \\
\text { - seine net } \\
\text {-rod \& line } \\
\text { - dewatering } \\
\text { - poisoning }\end{array}$ & $\begin{array}{l}\text { - fixed costs range from very low to moderate } \\
\text {-labour intensive } \\
\text {-moderate to high energy requirements } \\
\text { - higher skill requirements }\end{array}$ \\
\hline
\end{tabular}

fishing may almost always be possible, the most rewarding methods or locations can be permanently or seasonally beyond the means of the poorest. Béné (2003) provides examples of this kind of "economic exclusion" (p. 960), noting cases where costs of licenses, bribes or fees to government or traditional authorities together with the costs of fishing gear exclude poor households from either all or the best fisheries.

In addition, for the poorest households and as an influence on exploitation levels, the division between passive and active fishing methods in Table 2 may be at least as important as the costs of entry to fishing. Active fishing methods are much more labour intensive with a higher opportunity cost in terms of time and energy. Arguably they also require greater skill and knowledge. This has implications for analysis of part-time and gender differentiated fishing practices as discussed below.

In allocating own labour, individuals and households (particularly the poor and malnourished) may consider not only the time cost but also the energy cost and other hardships of an activity. Most fishing activities may require less energy use than many farm tasks and may be attractive to the poor. Research on the energetics of fishing would face methodological problems and studies are lacking, ${ }^{16}$ but it is worth noting that passive fishing methods in accessible water bodies may be one of few productive activities open to the sick, aged or otherwise disabled. ${ }^{17}$ On the other hand, some fishing methods may be considered difficult or dangerous. Apart from obvious weather and accident-related risks, long hours of exposure or immersion in water may leave people prone to diseases or parasites.

Fishing at night or in the early hours is also a common practice, using time not otherwise used for productive activities. Work at night is another under-researched area, at least in terms of effects on people rather than catches. ${ }^{18}$ The discomforts and insecurity of night work may be a barrier to entry, particularly for women. Alternatively, the low energy requirements of passive fishing at night may complement more strenuous daytime employment (again relevant to the merits of part-time fishing). Other factors that influence entry to fishing, particularly for women, may be time and travel cost to the

\footnotetext{
${ }^{16}$ Sillitoe (2002) provides a general review relevant to farming, hunting and gathering.

${ }^{17}$ Examples of this were observed in southern Laos.

${ }^{18}$ A discussion of night irrigation by Chambers (1988) is an exception.
} 
fishery, the need to and cost of taking meals away from home, and security (day or night). The recreational value of fishing is a further factor that is considered below.

Although it is necessary to be cautious in making generalisations, it can be observed that fishing by part-time fishers, poorer households and women and children tends towards fishing in open access water bodies, using low cost gear and labour rather than capital intensive methods. This will often (but not exclusively) involve passive fishing methods and be in pursuit of dispersed small species in shallow water or dispersed fry in the flood season. Using the terminology of the ethnographic literature on "hunting and gathering" societies, it can be regarded as "gathering" rather than "hunting", being a lower risk for the investments of time, energy and capital made and with lower but more constant returns for effort than hunting of either game animals or large aquatic species (Lee, 1998). It can also be regarded as an "immediate return" activity (Woodburn, 1998). Providing an immediate and direct return for labour it needs little investment in and control over assets and can be an individualistic activity that does not require collective action, pooling of labour or other forms of community cohesion.

In contrast fishing by full-time fishers, wealthier households and by men tends towards use of higher cost gear, boats and active fishing methods in pursuit of larger and higher value species in deeper water or is concentrated on adult fish in the dry season. This will usually offer higher risks and higher but more infrequent and unpredictable returns for effort. With more of the characteristics of a "delayed return" activity (Woodburn, 1998), it may create incentives for collective action, particularly to enforce temporal or spatial restrictions on fishing access and protect returns on the investments in specific assets made (e.g. specialised boats and gear and fishery enhancements).

Similarly there are relationships between the dynamics of a multi-species fishery, as exploitation changes over time, and fishing methods. As fishing pressure on stocks intensifies, a characteristic sequence of events is that the largest species successively disappear from the catch and may become locally extinct. Successors are similarly fished out and substituted by smaller species until the catch consists only of the young of the smallest species. Such a process of "fishing-down" may ultimately lead to catches only of the "young-of-the-year" as they return to the river from the floodplain (Welcomme, 1999) and incentives to manage the fishery and restrict access decline. Thus in terms of methods, catch composition, returns for labour and ease of entry, fishing tends towards that practised by the poor and is more likely to become an activity of last resort. This is a relatively under-researched area but one that highlights the importance of relationships between trajectories of change in the biological characteristics, livelihood functions and institutional characteristics of inland fisheries.

2.2.3. The micro, meso and macro economic environment. Neglect of markets and their influence on livelihoods and poverty has been a gap in much of the conceptualisation and application of livelihoods analysis, although included in Table 1 . This neglect can lead to failure to identify livelihood opportunities and constraints arising from market processes and development (Dorward et al., 2002). These are related to macro and meso level changes in national and local economies, including: wider processes of growth; increased competition; technological change; the integration of commodity and factor markets and their accessibility for the poor; institutional development that supports and coordinates markets; and conflicts between the interests of the poor and non-poor (Box A, Figure 2). Livelihood analysis that focuses (however usefully) only on immediate micro level opportunities for and constraints on households can overlook these issues and how they influence trajectories of change in key variables such as the opportunity cost of labour (Box E, Figure 2) or choice of livelihood strategies (Box G, Figure 2). 
A leading example is the state of the rural non-farm economy and whether it is a residual sector offering only coping activities and absorbing labour displaced from traditional activities of farming and fishing etc., or a dynamic one creating new jobs, exerting upward pressure on wages and with livelihood diversification as a positive adaptation leading to accumulation by rural households (Ellis, 1998; Reardon et al., 2000; Start, 2001). Another example is that, in the absence of reliable markets from which to purchase affordable food, households will tend to prioritise labour use in subsistence activities, such as cultivation of food crops, fishing for own consumption and gathering of wild foods and commodities such as firewood from any open access forests (Poulton et al., 2001).

A third example is that fragmented and poorly functioning credit markets, combined with inability to offer land as collateral, may leave fishing households indebted to informal lenders, exacerbating overfishing through the need to meet onerous repayment obligations. This also illustrates that there may be links between market development (Box A, Figure 2) and the institutional environment (Box D). The capacity of fishing communities to regulate access and fishing effort is similarly constrained by indebtedness or non-accessibility of credit (Payne, 2000).

2.2.4. The institutional environment. Institutions are critical in determining rights of different groups over resources. Béné (2003) suggested that the latter are the outcome of four processes of discrimination and intrasectoral exclusion: economic exclusion, social marginalisation, class exploitation and political disempowerment. Economic exclusion was considered above and the others are noted as important elements of the "institutional environment" in Box D (Figure 2) without repeating the exposition and examples that Béné provides.

Two other important issues are highlighted in Figure 2. First that the same processes of discrimination and exclusion may apply to other common property resources (CPRs) and to factor markets in which households access land, labour and capital, in both cases influencing the opportunity cost of own labour. Second that a further set of wider governance issues are part of the institutional environment and may determine a community's (or government agency's) capacity to manage a fishery, including enforcement of any regime-regulating rights of access. Both of these issues are well addressed by a wider literature and there is no scope for further exposition here.

2.2.5. Fisher household characteristics and objectives and the livelihood functions of fishing. A major deficiency of the paradigm depicted in Figure 1 is that whilst cited cases of fishing as an activity of last resort pursued by the poor and marginalised are numerous in the literature, ${ }^{19}$ there are also many examples that contradict this view (for example, Kremer, 1994; Garaway, 1999; Allison \& Ellis, 2001; Smith et al., 2001; Béné \& Neiland, 2003). These highlight first that fishing can be an activity of households who, if not wealthy in absolute monetary terms, certainly have incomes and living standards above those of the poorest groups in the same region and second that fishing may be pursued for a range of livelihood objectives beyond those of bare subsistence.

Recognition of the diverse functions that fishing can perform in the livelihoods of rural households follows from livelihoods analysis and a broad concept of poverty as described above. A typology of these functions is presented in Table 3 (expanding on Box $G$ in Figure 2). These functions will not generally be captured in any simple comparison of returns from fishing to opportunity costs but

\footnotetext{
${ }^{19}$ Table 3, p. 956 in Béné (2003) lists references using this concept.
} 
nevertheless will influence labour allocation decisions and hence fishing effort and its outcomes (Boxes $\mathrm{H}$, I and J, Figure 2).

The first two rows of Table 3 highlight contributions to survival or subsistence strategies and examples of the regional importance of inland fisheries to food production and nutrition were given in Section 1 above. Fish may provide $80 \%$ of dietary protein and micronutrients in parts of South Asia (Brautigam, 1999) and the rich species diversity of inland fisheries also contributes to livelihoods as more diverse fish stocks may supply a wider range of micronutrients and vitamins (Haraksigh-Thilsted et al., 1997), as well as satisfying varied consumption preferences. Small fish, typically eaten whole (and likely to be the product of heavily exploited tropical fisheries as discussed above), are also particularly rich sources of micronutrients and vitamins (Haraksigh-Thilsted et al., 1997). It is worth emphasising the high potential productivity of tropical inland fisheries, that almost the entire catch is consumed with practically no "bycatch" (FAO, 2000), and that these nutritional benefits are often accessible to the poorest.

Whilst few of the poorest households may survive on fishing alone, the first row in Table 3 represents fishing as a primary source of livelihood and an activity of last resort. The second row represents a traditional livelihood strategy that is inherited rather than the result of impoverishment or displacement and one that is widespread amongst established fishing communities. The complementarities in labour use with farming are cited because fishing is often a part-time activity for those also engaged in farming or other rural livelihoods (e.g. Kremer, 1994; Smith et al., 2001; Béné \& Neiland, 2003). This is another reason why the paradigm of Figure 1 is too simplistic. At the margin the labour opportunity cost of parttime fishing, or passive fishing done together with farm tasks, other work or overnight, will be much lower. People may not be driven to fish by low returns elsewhere but attracted to fish by high returns relative to costs, obtained alongside a primary occupation or in return for sacrifice of leisure rather than alternative work. Residential location or work in the fields can favour fishing by farmers and farm labourers, not least where flooded rice paddies and nearby water bodies may provide fish habitats. Travel to and from fields can also provide opportunities to check gear such as traps or gill nets. There is a gender dimension to this as part-time and passive fishing may be suited to the needs of women who cannot allocate longer periods for "active" or full-time fishing given their burden of farm and household tasks.

Table 3. Livelihood functions of fishing as household incomes rise and livelihood strategies develop.

\begin{tabular}{|c|c|}
\hline Livelihood strategy & Livelihood functions of fishing \\
\hline 'Survival' & $\begin{array}{ll}\text { - } & \text { Subsistence (food production and income) } \\
\text { - } & \text { Nutrition - protein, micronutrients, vitamins }\end{array}$ \\
\hline 'Semi-subsistence' diversification & $\begin{array}{l}\text { - Own consumption - food security and nutrition } \\
\text { - Complementarities in labour use with farming } \\
\text { - Means for barter, or for participation in reciprocal exchange and social networks } \\
\text { - Occasional cash source } \\
\text { - Diversification for: } \\
\text { labour and consumption 'smoothing' } \\
\text { risk reduction } \\
\text { as a coping strategy/buffering against shocks }\end{array}$ \\
\hline 'Specialisation' (as fishers) & $\begin{array}{l}\text { - Market production and income } \\
\text { - Accumulation }\end{array}$ \\
\hline 'Diversification for accumulation' & $\begin{array}{ll}\text { - } & \text { Accumulation } \\
\text { - } & \text { Retention in a diversified accumulation strategy } \\
\text { - } & \text { Recreation }\end{array}$ \\
\hline
\end{tabular}


In this livelihood strategy, fishing is an "opportunistic endeavour" (Allison \& Ellis, 2001, p. 386) to which effort allocated can vary flexibly according to the input available (primarily labour) and in response to returns to be made.

For rural households returns from fishing may also accrue in ways other than simply own consumption or income. Even subsistence and part-time fishers will make occasional catches that are surplus to own needs and given low storability and poor market access, fish can become a means for reciprocal exchange and participation in social networks. For example, from a survey of four villages in Champassak province, Laos, Noraseng et al. (1999) report that a small but significant proportion of fish passing through households was given by relatives and neighbours, confirming a significant role for kinship and social networks in food security. Similarly, from a survey in Savannakhet province, Laos, Garaway (1999) found that $10 \%$ of household fish supply was received as gifts, reciprocal exchange or payment for labour.

Where there is market access, fishing may also provide a ready source of cash for subsistence or semisubsistence producers with few other sources outside crop harvest periods but more frequent expenditure needs (or emergency needs such as for healthcare). In Laos, for example, Noraseng et al. (1999) found that income from intra-village and intra-district trade between fish-surplus and fish-deficit villages was an erratic but lucrative boost to cash income. Garaway (1999) found that sale of occasional surpluses provided a valuable source of cash, particularly for poorer households with less land and more time to fish. It was also notable that in southern Laos selling of fish and immediate control of the cash generated was usually in the hands of women. In an informal survey of fishing households in Sri Lanka the authors noted cases of landless households with limited access to credit that used fishing to generate cash, then invested in other enterprises such as a village shop or power tiller hire. Béné \& Neiland (2003) found that respondents in the Lake Chad basin appreciated the capacity of fishing to generate "instantaneous income surplus" (p. 9) in return for investment in fishing inputs, a substantial advantage over the delayed returns from investment in farming in a very risky environment and also an example of fishing as a "buffering" mechanism as discussed below.

Diversification is itself a key feature of this livelihood strategy and is defined as the process by which rural families construct a diverse portfolio of activities and social support capabilities in order to survive and to improve their standards of living (Ellis, 1998). Although agriculture usually dominates, many rural households have livelihood strategies that merge farming, hunting and gathering, labouring and micro enterprise, and in regions endowed with aquatic resources, fishing may be valuable within this mix. Sustainable livelihoods require adequate and stable flows of income and consumption all year round, but seasonality in farming, fishing and other activities causes variation in labour use and food security because of the mismatch of uneven income streams and continuous consumption requirements. Labour shortages in peak periods can also be compounded by seasonal ill health or low energy intake. Diversification can reduce the adverse effects of seasonality by utilising labour and generating alternative income during off-peak periods. Diversification also reduces the risk of losing all income sources simultaneously as a result of climatic or other shocks (Ellis, 2000; Start, 2001) and fishing can be one of several coping or buffering mechanisms that help to maintain minimum consumption levels in the face of external risk factors. ${ }^{20}$ Diversification can thus contribute to labour and consumption smoothing, and risk management and part-time fishing can be an accessible source of these functions for the poor.

\footnotetext{
${ }^{20}$ Table 2, p. 381, in Allison \& Ellis (2001) lists examples of such mechanisms from a range of artisanal marine and inland fisheries.
} 
For example, the itinerant fishers who dominate inland fishing in southern India belong to lower castes, are excluded frlom many benefits of a settled life including education and have few conspicuous assets. Nonetheless, their income appears to exceed that of many local farming households precisely because their itinerant life allows them to exploit resources and jobs where they are abundant and avoid seasonal shocks and indebtedness (Lorenzen, pers. obs.).

A common pattern of diversification in relation to household wealth has been observed (Maxwell et al., 2001; Start, 2001) and this underlies the hierarchy of strategies in Table 3. Diversification can arise as a means of survival or of advancement through exploitation of new opportunities. Poor households tend to have diversified livelihoods because of insufficient land (or fishing space), labour or capital to allow them to specialise. Their combined activities may offer less vulnerability than specialisation, but lower average returns for labour and no escape from poverty. Richer households may diversify (as in the fourth row of Table 3) because income growth through specialisation is constrained by limits of scale (e.g. farm size, fishing space, effective demand, labour needs) or remains subject to risk and because they have accumulated the assets needed to exploit new remunerative activities. As a result genuine specialisation in fishing (or farming) for the market is most likely to be by households towards the middle of the income range (even if still poor in absolute terms).

Specialisation in fishing (third row of Table 3) should achieve higher returns for effort, but this may require investment in specific assets: in physical capital (e.g. boats and gear), social capital (e.g. relationships within marketing chains and participation in fishery management institutions) and human capital (skills and knowledge). Sustaining returns on these investments requires effective resource management and access restrictions, but as noted above, an accumulation of specific assets may reduce mobility from fishing if these are weak and returns decline. Limits to scale are also more likely in inland than marine fisheries because of: limited fishing space and strong competition for its use; lesser technological economies of scale (except in the largest water bodies); lack of purchasing power and poor market infrastructure, access and integration in remote areas which together limit effective demand; and equally poor access to credit. These conditions influence fisher incomes and explain why genuine specialisation in inland fishing is relatively rare and why most households or individuals that fish do so as part of a diversified livelihood strategy. Also why investment in fishing assets tends to remain low, preserving economic mobility, but leaving any potential for more commercialised production underexploited because investments in resource management, marketing and adding value through processing are not forthcoming.

Where it exists, specialisation tends to occur in large water bodies such as lakes and reservoirs that offer fishing opportunities throughout the year and in the presence of reasonably developed markets or marketing networks. Because of their seasonal flows and fish migrations only the lower reaches of rivers tend to support specialised fishing, but reservoir construction in the upper reaches can precipitate the emergence of specialisation, either locally or after migration of fishers from coastal areas (as has been common, for example, in India and Sri Lanka). Where inland fisheries produce a significant volume of high value fish, marketing chains usually develop. For example, major carps moved to Calcutta from all over India, Nile perch to Europe from Lake Victoria, or catfish to Venezuela and Colombia from the Brazilian Amazon.

In most cases diversification into new higher return activities is more likely than specialisation in fishing as household assets and incomes rise (fourth row of Table 3). This may provide higher and less variable income in aggregate and feed back into income growth by reducing risk aversion and financing input and investment. Fishing income will decline as a proportion of total household income but the 
activity is likely to be retained in the household "portfolio", particularly in periods when returns from fishing exceed those of alternative activities and as a part-time activity for own consumption and recreation. Fishing will also tend to retain relatively more importance where any constraints on the mobility of labour apply, or for farming households for whom the benefits of part-time fishing are most accessible. For example, in Thailand diversification by fishing households (and often out migration to urban areas) has reportedly been driven by low and variable returns in fishing, new employment opportunities and rising economic expectations. However, out migration can be temporary and cyclical unless households have accumulated the social and human capital to gain entry to permanent well-paid employment. For poorer households it may only be children for whom sufficient resources have been scraped together for education who can permanently escape fishing as a source of livelihood (Bath University Centre for Development Studies, 1994). In northeast Thailand, fishing has tended to remain important in the livelihoods of middle-income farming households, while poorer households tend to leave rural areas seasonally or permanently to engage in wage labour (Garaway, 1995).

Lastly the recreational function of fishing is known to be of high value in developed economies ${ }^{21}$ and despite little research, its importance for people in rural regions of developing countries should not be neglected. (Thus although it is noted in the fourth row of Table 3 it may be of value for lower income households pursuing other livelihood strategies as represented by the other rows). For example, among the Batek in Malaysia Endicott found that "women often go fishing with their children as a way of filling an hour or two after other work has been completed" (Endicott, 1980, p. 634) and people often explained that they were tired of sitting around camp and just playing around at fishing (Endicott, 1979). ${ }^{22}$ The authors noted similar responses in informal household interviews conducted in southern Laos. Thus there is often a personal satisfaction from fishing which may be greater than in other productive activities (Cunningham, 1993) and the utility gained from fishing (particularly part-time) cannot always be solely measured by income or compared only to the opportunity cost of labour and other inputs.

2.2.6. Livelihood outcomes. In terms of livelihood outcomes this paper is primarily concerned with Box $\mathrm{J}$ in Figure 2, noting that as well as the level of household income derived from fishing, its variability, timing, convertibility into cash and use as a means of exchange in support networks can be important, as noted above. The framework should be seen as dynamic and the outcomes will feedback to influence the situational variables or attributes in Boxes A to D.

Outcome in terms of environmental sustainability will similarly be the result of and ongoing influence upon the patterns of interaction highlighted in Figure 2 but can be complex and difficult to predict. It may generally be expected that biodiversity conservation will be synonymous with safeguarding the livelihoods of the people dependent on the resource, and the role of fisheries in the livelihoods of the poor is now frequently invoked in support of conservation interests. However, the relationship between conservation and livelihood benefits is less straightforward than it may initially seem. Some highly modified and, in conservation terms, degraded systems, support very productive fisheries. Reservoirs in seasonally dry areas, for example, may increase local and regional fisheries production. Even where overall production impacts are clearly negative, modified water resources may increase availability of aquatic resources in critical seasons or to particularly vulnerable groups. On the other hand, high levels

\footnotetext{
${ }^{21}$ For example, anglers in Canada spend 2.9 billion Canadian dollars a year on goods and services directly related to fishing and in 1996 anglers in the USA spent US\$447 million on fishing licences alone (Revenga et al., 2000).

${ }^{22}$ Both cited in Bird-David (1998).
} 
of resource exploitation and some fisheries enhancement measures may have an ecological impact that may even exceed the impact of water resources development. Hence, whilst sustaining both livelihoods and biodiversity are generally elements of a sustainable development paradigm, the relationship between these requires detailed assessment for a given situation.

\section{Using an improved understanding of the livelihood functions of inland fisheries}

This paper has emphasised the importance of the socio-economic context within which fisheries are placed and the need for a more holistic approach to assessment of the role of inland fishing in rural livelihoods. This has relevance to water policy, as new perspectives and approaches to fishery management within the context of integrated water resource management are currently needed, and these must seek to balance conservation and livelihood objectives within a sustainable development paradigm.

The analysis above has highlighted that in contrast to the stereotype that all fishers are poor and that fishing is the activity of last resort, actual fishing communities are likely to be varied in terms of wealth, social status, fishing methods and the livelihood roles performed by fishing (as confirmed, for example, by the observations of Kremer, 1994; Béné \& Neiland, 2003). Wealthier members of fishing communities are likely to be more specialised in fishing than those poorer members and may make significant capital investments in fishing methods or in purchase or leasing of access rights. Resulting differences in fishing capability lead to variation in returns for labour and net income from fishing (and in total income in the absence of accessible equally remunerative alternatives to fishing). Any surplus assets are likely to be initially invested in specialisation rather than non-fishing diversification, although limits of scale may rapidly apply as discussed above. In contrast the poorest fishers cannot invest in better fishing methods and are likely to suffer restricted access to the best fishing areas or during the best periods (for example, dry season access may be at a particular premium). Like marginal farmers these marginal fishers will tend to have more diversified livelihoods.

Such differentiation can be both inter- and intra-household. Compared to farming, gender divisions by enterprise or task in fishing can be either more culture or location specific, or much less apparent. Divisions by enterprise as defined by fishing method, location and species are more common, but divisions by tasks such as mending nets or making traps may also exist. Compared to fishing by men, fishing by women tends to correspond to that by poorer fishers, that is, relatively labour intensive, low input and low value in terms of returns for effort, but not necessarily in its livelihood contribution, given household status.

These insights are important because wide acceptance of the "last resort stereotype" may influence policy. First, it attaches a positive attribute to open access in contrast to most opinion on management of open and common property resources (Béné, 2003). Second, the notion that fisheries provide a safety net for the landless and destitute may influence not just fisheries policy, but also management of other natural resources and other initiatives to sustain livelihoods in rural areas. Third it may contribute to the relative neglect of inland fisheries by public policy compared to other productive rural sectors.

There is thus a need for greater differentiation of fishery management policies than often currently exists and recognition that the best combination of policies may be very location specific. A better understanding of livelihoods complicates fisheries management by requiring a more complex set of objectives. There are potential trade-offs between goals of production, efficiency, 
conservation and poverty alleviation, and parallels with other sectors such as livestock, in a disjunction between most practice that has emphasised productivity improvements and top-down regulation of stock levels and recognition of the importance of livelihood functions such as diversification and buffering mechanisms. Using the livelihoods typology of Table 3 and the framework depicted in Figure 2, Table 4 presents an assessment of policy priorities and instruments for four scenarios.

In the scenario described in the first row of Table 4 overexploitation of the resource, and fisher households suffering from extreme poverty, are likely. Fishing is the main source of subsistence for fishing households and is probably the livelihood of last resort for a significant number of landless and disadvantaged households. In such a scenario the livelihood role played by fishing is clearly worth preserving but conventional attempts to improve fishery management and productivity are likely to be problematic.

First, the characteristics of fishers (lacking appropriate social capital and other assets; Box B, Figure 2) and their fishing practices (mainly "immediate return"; Box C, Figure 2) suggest that attempts to establish community-based fisheries management may be ill fated for all but the most favourable locations, because incentives for collective action, safeguards for investments, household assets and community cohesion may all be too weak. Second, many assessments of the institutional environment for fisheries in developing countries (Box D, Figure 2) emphasise the limitations of state-led fisheries management (see for example Allison \& Ellis, 2001). Third, other common measures to increase productivity by raising the efficiency of fishing effort (for example, through credit provision and technology transfer) will not raise incomes unless the number of fishers is reduced to maintain a sustainable long run catch rate.

In these circumstances the policy priority should be to create alternative employment and microenterprise opportunities in the rural economy (addressing the scenario primarily through Box A, Figure 2). Although tourism, forestry and manufacturing may all play a role and well-integrated crosssectoral development policies are needed, it is likely that agriculture will be the main driver of this (Smith, 2004). In the short term, or in remote and resource poor regions, welfare safety nets such as "food for work" programmes may also be needed. Indeed "enhancement" ${ }^{\text {"2 }}$ of a fishery by the state simply to provide subsistence and employment for the maximum number of people might be an appropriate short-term safety net, but neither option offers lasting poverty reduction. Retention of the benefits of part-time fishing may also be desirable for some households and aiming for complete withdrawal from fishing may not be necessary. The goal is simply to raise the labour opportunity cost of fishing sufficiently to have both poverty reduction and resource conservation benefits (Box E, Figure 2).

This scenario has been observed for coastal lagoon and reservoir fisheries in the relatively economically depressed region of south-eastern Sri Lanka. These have provided a livelihood for significant numbers of the landless poor, including some of the second generation of "dry zone" settlers for whom land is not available. However, successive problems of drought, competition for water with irrigated farming and over-fishing has led many to move on to other livelihoods of "last resort" such as firewood collection, shell mining and lime making (Kularatne, 1999; Nguyen Khoa et al., 2002).

\footnotetext{
${ }^{23}$ E.g. Stocking of hatchery-reared seed fish and restoration of spawning and nursery habitats that are common property. Appropriate institutional development is necessary to achieve cost recovery and protect property rights and this is usually linked to strengthening of community resource management.
} 
Table 4. Policy priorities for varying livelihood and fishery scenarios.

\begin{tabular}{|c|c|c|c|c|c|c|}
\hline Livelihood strategy & Fishery characteristics & Fisher characteristics & $\begin{array}{l}\text { Livelihood functions } \\
\text { and characteristics } \\
\text { of fishing }\end{array}$ & Example & $\begin{array}{l}\text { Main policy } \\
\text { objectives }\end{array}$ & $\begin{array}{l}\text { Policy } \\
\text { instruments }\end{array}$ \\
\hline \multirow[t]{4}{*}{$\begin{array}{l}\text { (1) Main source of } \\
\text { subsistence and } \\
\text { livelihood } \\
\text { of last resort }\end{array}$} & $\begin{array}{l}\text {-Open-access and likely to be } \\
\text { over exploited }\end{array}$ & -Landless & -Subsistence & $\begin{array}{l}\text {-Landless fishers in } \\
\text { southeastern Sri Lanka } \\
\text { (Nguyen Khoa } \\
\text { et al., 2002) }\end{array}$ & $\begin{array}{l}\text {-Reduce number } \\
\text { of fishers }\end{array}$ & $\begin{array}{l}\text {-Alternative } \\
\text { employment } \\
\text { in the rural economy }\end{array}$ \\
\hline & & $\begin{array}{l}\text {-Marginalised or } \\
\text { excluded from } \\
\text { labour market }\end{array}$ & $\begin{array}{l}\text {-Full-time or significant } \\
\text { part-time }\end{array}$ & & $\begin{array}{l}\text { - Resource } \\
\text { conservation }\end{array}$ & $\begin{array}{l}\text {-Welfare 'safety } \\
\text { nets' }\end{array}$ \\
\hline & & $\begin{array}{l}\text {-May be displaced or } \\
\text { seasonally migrant }\end{array}$ & $\begin{array}{l}\text {-Particularly important } \\
\text { to women, children, } \\
\text { the aged, and infirm }\end{array}$ & & & $\begin{array}{l}\text {-Enhancement of } \\
\text { the fishery as a 'safety } \\
\text { net' }\end{array}$ \\
\hline & & -Very poor & & & & \\
\hline \multirow[t]{3}{*}{$\begin{array}{l}\text { (2) Traditional } \\
\text { diversified } \\
\text { subsistence or } \\
\text { semi-subsistence }\end{array}$} & $\begin{array}{l}\text {-Open access, but possibly } \\
\text { self-regulating depending on } \\
\text { population pressure on land } \\
\text { and other natural resources }\end{array}$ & -Landless labourers & -Food security & $\begin{array}{l}\text {-Poor farming households } \\
\text { in southern Laos } \\
\text { (Smith } \text { et al., 2001) }\end{array}$ & $\begin{array}{l}\text {-Sustainability of } \\
\text { traditional } \\
\text { livelihoods }\end{array}$ & - 'Light' regulation \\
\hline & & -Marginal farmers & $\begin{array}{l}\text {-Buffering, coping, } \\
\text { smoothing }\end{array}$ & $\begin{array}{l}\text {-Southern African inland } \\
\text { fisheries (Jul-Larsen \& } \\
\text { van Zwieten, 2002) }\end{array}$ & $\begin{array}{l}\text { - Resource } \\
\text { conservation } \\
\text { and enhancement }\end{array}$ & $\begin{array}{l}\text {-Maintain access for } \\
\text { the poor through } \\
\text { enabling institutions } \\
\text { and 'permeable } \\
\text { barriers to entry' }\end{array}$ \\
\hline & & -Hunter-gatherers & $\begin{array}{l}\text {-Source for cash or } \\
\text { reciprocal exchange } \\
\text {-Important to women } \\
\text { and children }\end{array}$ & & & $\begin{array}{l}\text {-Fishery } \\
\text { enhancements }\end{array}$ \\
\hline \multirow[t]{3}{*}{$\begin{array}{l}\text { (3) Specialist, } \\
\text { full-time fishing }\end{array}$} & $\begin{array}{l}\text { - Needs restricted access and } \\
\text { effective management } \\
\text { measures to sustain incomes }\end{array}$ & $\begin{array}{l}\text {-Fisher households } \\
\text { and communities }\end{array}$ & $\begin{array}{l}\text {-Income and } \\
\text { accumulation }\end{array}$ & $\begin{array}{l}\text {-Lagoon fisheries in SE } \\
\text { Sri Lanka } \\
\text { (Kularatne, 1999) }\end{array}$ & $\begin{array}{l}\text {-Sustainable } \\
\text { commercial } \\
\text { fishery }\end{array}$ & $\begin{array}{l}\text {-Strengthen } \\
\text { community } \\
\text { management, or } \\
\text { regulate exclusive } \\
\text { private access rights }\end{array}$ \\
\hline & $\begin{array}{l}\text {-May be subject to } \\
\text { 'monopolisation' of access } \\
\text { rights by individuals }\end{array}$ & & $\begin{array}{l}\text {-Mainly male } \\
\text { dominated }\end{array}$ & $\begin{array}{l}\text { - Some communities in } \\
\text { Bangladesh (Kremer, } \\
\text { 1994) }\end{array}$ & & $\begin{array}{l}\text {-Fishery } \\
\text { enhancements }\end{array}$ \\
\hline & & & & & & $\begin{array}{l}\text {-Modernisation of } \\
\text { methods } \\
\text {-Credit and market } \\
\text { access } \\
\text {-Processing and } \\
\text { marketing } \\
\text {-Effective access } \\
\text { restrictions }\end{array}$ \\
\hline
\end{tabular}


Table 4. (continued)

\begin{tabular}{|c|c|c|c|c|c|c|}
\hline Livelihood strategy & Fishery characteristics & Fisher characteristics & $\begin{array}{l}\text { Livelihood functions } \\
\text { and characteristics } \\
\text { of fishing }\end{array}$ & Example & $\begin{array}{l}\text { Main policy } \\
\text { objectives }\end{array}$ & $\begin{array}{l}\text { Policy } \\
\text { instruments }\end{array}$ \\
\hline \multirow[t]{2}{*}{$\begin{array}{l}\text { (4) Diversified } \\
\text { 'accumulation' } \\
\text { strategy }\end{array}$} & \multirow[t]{2}{*}{$\begin{array}{l}\text {-Open access and probably } \\
\text { self-regulating given 'light' } \\
\text { regulation by community } \\
\text { or state }\end{array}$} & $\begin{array}{l}\text {-Farming households } \\
\text { with surplus labour }\end{array}$ & $\begin{array}{l}\text {-Some residual } \\
\text { buffering function, } \\
\text { but of declining } \\
\text { importance }\end{array}$ & $\begin{array}{l}\text {-Wealthier farmers in } \\
\text { southern Laos } \\
\text { (Smith } \text { et al., 2001) }\end{array}$ & $\begin{array}{l}\text {-Ecological } \\
\text { conservation }\end{array}$ & - 'Light' regulation \\
\hline & & $\begin{array}{l}\text {-Workers with regular } \\
\text { casual or permanent } \\
\text { employment }\end{array}$ & $\begin{array}{l}\text {-Own-consumption } \\
\text { and recreation }\end{array}$ & $\begin{array}{c}\text {-Farmer-fishers in SE } \\
\text { Sri Lanka (Nguyen } \\
\text { Khoa } \text { et al., 2002) }\end{array}$ & & $\begin{array}{l}\text {-Ecological } \\
\text { protection measures }\end{array}$ \\
\hline
\end{tabular}


Improved management of the fisheries is essential but this should aim to maintain an open access resource as a safety net for the rural poor in the short term and then to develop more productive commercial fisheries once adequate alternative employment has been created.

For the second scenario the priority is to maintain the benefits provided by inland fisheries in traditional and diversified livelihood strategies, particularly for the more vulnerable members of communities and those lacking the asset endowments to take advantage of any new opportunities provided by rural economic growth. There is a need to prevent overexploitation of the resource but protect the access rights of the poor. This may require assessment and measures at watershed rather than just water body level and will involve policies acting via Boxes C and D in Figure 2.

Assessment of fishery characteristics (Box C, Figure 2) and the livelihood function of fishing (Box G) are important as overexploitation may not be a severe risk if fishing is primarily part-time and opportunistic, as in this scenario an open access fishery may be largely self-regulating, with fishing effort declining as returns for effort decline compared to other household activities (particularly for multispecies tropical inland fisheries for which combined yields may be resilient over a wide range of fishing pressure, as described above). Institutions to regulate access remain important, but need not take the form of most conventional "top-down" interventions such as fixed territorial rights and licensed catch limits based on estimates of the economically optimal catch from a static equilibrium fish stock (Allison \& Ellis, 2001). Relatively "light" regulation of access and fishing practices may be sufficient. For example, seasonal restrictions at migration choke points and during low water levels to avoid depletion of stocks and other measures such as minimum net mesh sizes, if enforceable.

For the poor the need is to preserve economic mobility into and out of fishing and other activities, maintaining the diversification and buffering functions of these (Table 3). Such adaptability may be sustained by enabling institutions and "permeable barriers to entry" (Allison \& Ellis, 2001, p. 380). For example: traditional reciprocal access agreements between communities for fisheries and other common property resources and flexible local mechanisms to allow "outsiders" access at times of need.

Examples of the latter were observed by Garaway (1999), who found cases of effective communal management of access to water bodies in Laos that protected the resource whilst providing for subsistence fishing by poor households.

Also rather than seeking to modernise and improve the efficiency of fishing methods in ways that tend to be more accessible to wealthier households (credit and technology), it may be more appropriate to focus on fishery enhancements as a means of income improvement. Enhancements can boost the productivity of resources in common ownership and may provide higher returns on investment than modernisation, while remaining accessible to the poor. Livelihoods analysis and a broad conception of the determinants of poverty facilitate understanding of such advantages and prompt a focus on institutional development necessary for adoption of enhancement technologies.

Jul-Larsen \& van Zwieten (2002) suggest this scenario applies to the fisheries of Malawi, Zambia and Zimbabwe. They conclude that given serious and persistent macroeconomic recession the buffer function of these fisheries should take priority over their commercial development. The scenario has also been observed in southern Laos, which Bush (2003) cites as an example of where government resources are mainly spent on promoting aquaculture, although capture fisheries are more important to the poor. Aquatic resources are, however, relatively abundant in Laos and sustaining such a scenario may be more difficult elsewhere if population pressure is higher and household market orientation and economic expectations stronger. As with the first scenario, diversification and growth in non-fishing rural sectors are then needed, with the aim of a progressive transition for fishing towards the third and fourth scenarios in Table 4. 
The third scenario in Table 4 represents inland fishing as an independent sector and specialised occupation. Past fisheries policies and projects have tended to be oriented towards this, despite the fact (as discussed above) that it is usually only the case for a minority of households that fish. As rural economies develop, these specialists may continue as fishers because of: lifestyle preferences; comparative advantage resulting from inherited skills, investment in specific assets or command over premium spatial or temporal fishery access; or barriers to entry in other occupations. The potential for sustainable commercial fisheries to provide improved living standards for a limited number of full-time fishers may exist, but is typically underexploited. Such developments will need the type of measures listed in Table 4, although once scope for fishery enhancement, modernisation and economies of scale has been fully utilised, then further income growth for fishers can only come from further reducing numbers, adding value through processing and marketing developments, or again diversification of livelihood. Cunningham (1993), for example, notes that rents generated by restricted access can be extracted and invested outside a fishery to aid such diversification and contraction of the industry. Another issue is that "monopolisation" of access rights by one or a small number of private individuals can arise (for example, cases in Bangladesh and Cambodia) which may require state or community regulation. A similar issue is the contractual arrangements under which the holders of such rights may employ or contract those who actually do the fishing. Development of a sustainable commercial fishery thus requires particular attention to market development and institutions and how these influence fishing practices and exploitation levels (Boxes $\mathrm{C}$ and D, Figure 2).

In the fourth scenario in Table 4 households retain an interest in fishing as incomes rise but its importance within their portfolio of livelihood activities tends to decline and ecological conservation can become the priority policy objective. Opportunities to withdraw from fishing exist for these households and their demand for the resource is likely to be relatively self-regulating. If so, light regulation as described above may be sufficient to achieve conservation objectives, with particular provisions being made for endangered species or ecosystems. Such outcomes are conditional on assessment of the livelihood roles played by fishing and the degree of dependence of households on this activity (Box G, Figure 2).

The scenarios in Table 4 may represent transitions over time for households experiencing rural economic growth and rising incomes, but they may also represent the cross-section of households that fish within a catchment or even a water body. The reality is that these scenarios often co-exist, with fishing performing different functions for different households, or even members of the same household. Thus the generalisations in Table 4 are only an initial guide. Actual measures must take account of the complexity of local conditions, seek to resolve any trade-offs and be specifically adapted for the location. Effective processes of genuine stakeholder consultation and participation are likely to be valuable in seeking to achieve the appropriate location-specific policy mix (Nguyen Khoa et al., 2002).

\section{Conclusions}

This paper has reviewed existing explanations of livelihood outcomes in artisanal inland fisheries and extended them by considering a wider range of factors that may influence fishing effort and fisher incomes. This has been done by utilising a broad concept of poverty and the concepts of livelihood analysis, in particular recognition of household responses to external risk factors and the institutional and policy environment. The resulting analysis of the range of livelihood functions performed by fishing 
within a diversity of livelihood strategies reveals why the concept of fishing as an activity of last resort is too limited to guide policy and management measures.

A more comprehensive analytical framework has been developed and used to identify relevant policy objectives and instruments for different scenarios in terms of the role played by inland fishing in rural livelihoods. The analysis shows that diversity in fishing communities in terms of fishing practices, wealth and status can stem from differences in the asset endowment (Box B, Figure 2), livelihood strategies of fishers (Table 3 and Box G), methods of fishing (Table 2 and Box C) and rights over resources (Box D). It also shows that diverse and flexible measures tailored to local priorities and conditions are needed to ensure that poor people can access the livelihood benefits of inland fisheries whilst achieving conservation objectives. Detailed formulation of such measures needs further work, but this must be location specific and involve stakeholders representing all relevant interests.

\section{Acknowledgements}

This paper results from a collaborative project involving Imperial College London, ITAD Ltd., IWMI, the Regional Development Committee for Livestock and Fisheries in Southern Laos and the University of Kelanyia, Sri Lanka. Funding was provided by the UK Department for International Development, Knowledge and Research in Engineering Sectors Programme and the CGIAR Comprehensive Assessment for Agriculture. The comments of anonymous reviewers are also gratefully acknowledged.

\section{References}

Abell, R., Thieme, M. \& Lehner, B. (2002). Ecoregion Conservation for Freshwater Systems, With a Focus on Large Rivers. World Wildlife Fund, Washington, DC.

Ahmed, M. \& Lorica, M. H. (2002). Improving developing country food security through aquaculture: development-lessons from Asia. Food Policy, 27, 125-141.

Allison, E. H. \& Ellis, F. (2001). The livelihoods approach and management of small-scale fisheries. Marine Policy, 25, 377-388.

Almeida, O. T., Lorenzen, K. \& McGrath, D. G. (2002). The role of the fisheries sector in the regional economy of the Brazilian Amazon. In 2nd International Large Rivers Symposium. FAO, Rome.

Arthington, A. H., Lorenzen, K., Pusey, B. J., Abell, R., Halls, A., Winemiller, K. O., Arrington, D. A. \& Baran, E. (2003). River fisheries: ecological basis for management and conservation. In Proceedings of the 2nd International Large Rivers Symposium. in Welcomme, R. L. (ed.). FAO, Rome.

Bath University Centre for Development Studies (1994). The Study of the Floodplain in Southern Thailand. Bath Centre for Development Studies, University of Bath, Bath, UK.

Béné, C. (2003). When fishery rhymes with poverty: a first step beyond the old paradigm on poverty in small-scale fisheries. World Development, 31(6), 949-975.

Béné, C. \& Neiland, A. E. (2003). Contribution of inland fisheries to rural livelihoods in Africa: empirical evidence from the Lake Chad basin areas. In Second International Symposium on the Management of Large Rivers for Fisheries: Sustaining Livelihoods and Biodiversity in the New Millennium, 11-14 February, Phnom Penh, Cambodia.

Bird-David, N. (1998). Beyond "the original affluent society" : a culturalist reformulation. In Limited Wants, Unlimited Means. Gowdy, J. M. (ed.). Island Press, Washington, DC, pp. 115-138.

Brautigam, A. (1999). The freshwater biodiversity crisis. World Conservation, 30(3), 4-5.

Bush, S. R. (2003). Comparing what matters with what is done: fisheries and aquaculture in the Lao PDR. In Second International Symposium on the Management of Large Rivers for Fisheries: Sustaining Livelihoods and Biodiversity in the New Milennium, 11-14 February 2003, Phnom Penh, Cambodia. 
Chambers, R. (1988). Managing Canal Irrigation. Cambridge University Press, Cambridge.

Copes, P. (1988). Why are Fishing Incomes Often Low? A Critical Review of the Conventional Wisdom. Simon Fraser University, BC, Canada, 21 pp.

Cunningham, S. (1993). Fishermen's Incomes and Fisheries Management. Centre for the Economics and Management of Aquatic Resources, Portsmouth, 22 pp.

DFID (1999). Sustainable Livelihoods Guidance Sheets. Department for International Development, London.

Dorward, A., Poole, N., Morrison, J., Kydd, J. \& Urey, I. (2002). Critical linkages: livelihoods, markets and institutions. In Seminar on 'Supporting Institutions, Evolving Livelihoods'. 29-30 May. Bradford Centre for International Development, University of Bradford.

Ellis, F. (1998). Survey article: household strategies and rural livelihood diversification. Journal of Development Studies, 35(1), $1-38$.

Ellis, F. (2000). The determinants of rural livelihood diversification in developing countries. Journal of Agricultural Economics, 51(2), 289-302.

Endicott, K. (1979). Batek Negrito Religion: The World View and Rituals of a Hunting and Gathering People of Peninsular Malaysia. Clarendon Press, Oxford.

Endicott, K. (1980). Batek Negrito sex roles: behaviour and ideology. In Second International Conference on Hunting and Gathering Societies, Quebec, Canada.

FAO (Food and Agricultural Organization of the United Nations) (1996) Malawi Fishery Country Profile, FAO Fisheries Department Website: http://www.fao.org/fi/fcp/malawie.htm viewed 27 June 2000.

FAO (2000). The State of World Fisheries and Aquaculture. Food and Agriculture Organisation of the United Nations, Rome.

Garaway, C. J. (1995). Communal Ponds In Northeast Thailand Under Different Use Rights Systems: a participatory rural appraisal of their differing role in people's livelihoods. MSc Thesis, Imperial College, University of London.

Garaway, C. J. (1999). Small Waterbody Fisheries and the Potential for Community-Led Enhancement: case studies in Lao PDR. PhD thesis, Centre for Environmental Technology, Imperial College London.

Haraksigh-Thilsted, S., Roos, N. \& Hassan, N. (1997). The role of small indigenous species in food and nutrition security in Bangladesh. In International Consultation on Fisheries Policy Research in Developing Countries, 2-5 June, Hirtshals, Denmark.

Hoggarth, D. D., Cowan, V. J., Halls, A. S., Aeron-Thomas, M., McGregor, J. A., Garaway, C. J., Paine, A. I. \& Welcomme, R. L. (1999). Management Guidelines for Asian Floodplain River Fisheries. FAO, Rome.

Jensen, J. G. (2001). Managing fish, flood plains and food security in the lower Mekong Basin. Water Science and Technology, 43(9), 157-164.

Jul-Larsen, E. \& van Zwieten, P. (2002). African freshwater fisheries: what needs to be managed? Naga, Worldfish Center Quarterly, 25(3\&4), 35-40.

Kremer, A. (1994). Equity in the Fishery: A Floodplain in N.E. Bangladesh. Bath Centre for Development Studies, University of Bath, Bath, UK.

Kularatne, M. G. (1999). Fishermen Without Fish. The Effects of Productivity Decline in Lagoon Fisheries on a Fishing and Farming Community and its Use of Natural Resources: A Case Study of Malala Lagoon, Hambantota, Sri Lanka. International Institute for Aerospace Survey and Earth Sciences, Enschede, The Netherlands, 118 pp.

Lae, R. (1997). Does overfishing lead to a decrease in catches and yields? An example of two West African coastal lagoons. Fisheries Management and Ecology, 4, 149-164.

Lee, R. (1998). What hunters do for a living, or, how to make out on scarce resources. In Limited Wants, Unlimited Means. in Gowdy, J. M. (ed.). Island Press, Washington, DC, pp. 43-64.

Lewis, D. (1997). Rethinking aquaculture for resource-poor farmers: perspectives from Bangladesh. Food Policy, 22, 533-546.

Lorenzen, K., Nguyen Khoa, S., Garaway, C., Arthur, R., Kirkwood, G., Chamsingh, B., Litdamlong, D., Innes-Taylor, N. \& Siebert, D. (2000). Impacts of Irrigation and Aquaculture Development on Small-Scale Aquatic Resources. Final Technical Report, DFID Project R7235. Imperial College, London.

Lorenzen, K., Smith, L. E. D. \& Nguyen Khoa, S. (2002). Management of Irrigation Development Impacts on Fisheries. Final Technical Report, DFID Project R7793. Imperial College, London.

Maxwell, S., Urey, I. \& Ashley, C. (2001). Emerging Issues in Rural Development: An Issues Paper. Overseas Development Institute, London. 
McKenzie, W. (1979). Rational fishery management in a depressed region: the Atlantic ground fishery. Journal of the Fisheries Research Board of Canada, 36, 811-826.

MRC (1997). Greater Mekong Sub-Region State of the Environment Report. Mekong River Commission and United Nations Environment Programme, Bangkok.

Naylor, R. L., Goldburg, R. J., Mooney, H., Beveridge, M., Clay, J., Folke, C., Kautsky, N., Lubchenco, J., Primavera, J. \& Williams, M. (1998). Nature's subsidies to shrimp and salmon farming. Science, 282, 883-884.

Neiland, A. E. \& Sarch, M. T. (1994). A Socio-economic Analysis of Artisanal Fisheries in North East Nigeria: Executive Summary. Centre for the Economics and Management of Aquatic Resources, University of Portsmouth, Portsmouth.

Nguyen Khoa, S., Smith, L. E. D., Burton, M., Lorenzen, K. \& Garaway, C. (2002). Management of Irrigation Development Impacts on Fisheries: Sri Lanka Case Study. Final Technical Report, DFID Project R7793. Imperial College, London.

Noraseng, P., Hirsch, P., Manotham, S. \& Tubtim, K. (1999). A Report on Household Level Fisheries in Four Villages of Sanasomboun District, Champassak Province, Lao PDR. Indigenous Fisheries Development and Management Project, Department of Livestock-Fisheries, Vientiane.

Oakerson, R. (1992). Analyzing the commons: a framework. In Making the Commons Work: theory, practice and policy. Bromley, D. W. \& Feeny, R. (eds.). ICS, San Francisco, pp. 41-59.

Panayotou, T. (1982). Management Concepts For Small-Scale Fisheries: Economic and social aspects. Fisheries Technical Paper 228. FAO, Rome.

Panayotou, T. \& Panayotou, D. (1996). Occupational and Geographical Mobility in and out of Thai Fisheries. Fisheries Technical Paper 271. FAO, Rome.

Pauly, D., Christensen, V., Guenette, S., Pitcher, T. J., Sumaila, U. R., Walters, C. J., Watson, R. \& Zeller, D. (2002). Towards sustainability in world fisheries. Nature, 418, 689-695.

Payne, I. (2000). The changing role of fisheries in development policy. In Natural Resources Perspectives 59. Overseas Development Institute, London.

Poulton, C., Al-Hassan, R., Cadisch, G., Reddy, C. \& Smith, L. E. D. (2001). The Cash Crop Versus Food Crop Debate, DFID Crop Post Harvest Programme, Issues Paper 3, London.

Reardon, T., Taylor, J. E., Stamoulis, K., Lanjouw, P. \& Balisacan, A. (2000). Effects of non-farm employment on rural income inequality in developing countries: an investment perspective. Journal of Agricultural Economics, 51(2), $266-288$.

Revenga, C., Brunner, J., Henninger, N., Kassem, K. \& Payne, R. (2000). Pilot Analysis of Global Ecosystems: Freshwater Systems. World Resources Institute, Washington, DC.

Sen, A. (1981). Poverty and Famines: An Essay on Entitlement and Deprivation. Clarendon Press, Oxford.

Sillitoe, P. (2002). After the 'affluent society' cost of living in the Papua New Guinea highlands according to time and energy expenditure income. Journal of Biosocial Science, 34, 433-461.

Smith, L. E. D. (2004). Assessment of the contribution of irrigation to poverty reduction and sustainable livelihoods. International Journal of Water Resources Development, 20(2), 243-257.

Smith, L. E. D. (2001). The impact of technical change on rural livelihoods in a semi-subsistence economy: irrigation developments and aquatic resource use in Laos. In 74th Seminar of the European Association of Agricultural Economists, Livelihoods and Rural Poverty: Technology, Policy and Institutions. 12-15 September Imperial College London, Wye campus.

Start, D. (2001). Rural diversification: what hope for the poor? ODI Meeting on Rural Development Food Security: Towards a New Agenda. 16 May ODI, London.

Welcomme, R. L. (1999). Fisheries: enemies of biodiversity or tools for conservation? World Conservation, 30(2), $13-14$.

Welcomme, R. L. (2001). Inland Fisheries: Ecology and Management. Blackwell Science, Oxford.

Williamson, O. E. (1985). The Economic Institutions of Capitalism. The Free Press, New York.

Woodburn, J. (1998). Egalitarian Societies. In Limited Wants, Unlimited Means. Gowdy, J. M. (ed.). Island Press, Washington, DC. 